\title{
The Functional Motivation of the High Tone Syllable in Yorùbá: A Critique
}

\author{
Tèmítọ́pẹ́ Olúmúyìwá (Àkùngbá-Àkókó)
}

\begin{abstract}
Bisang and Sonaiya (1999) call the high tone syllable (the HTS) in Yorùbá language "an operator which actualises or validates the relationship between a predicate and a subject within a state of affairs". This paper shows that this view is faulty because it makes wrong predictions concerning the element in the language.
\end{abstract}

\section{Introduction}

A V-syllable having a high tone and known in Yorùbá linguistic literature as the high tone syllable or HTS for short, regularly occurs directly after the subject in Yorùbá declarative sentences. Its underlying form, ó (Awobuluyi 1992: 32; Bamgbose 1990: 180), always assimilates (sometimes vacuously) to the final vowel of the subject NP (Yorùbá words are all vowel final). Examples are:

\begin{tabular}{|c|c|c|c|c|c|c|}
\hline (a) & $\begin{array}{l}\text { Ayọ̀ } \quad \stackrel{0}{ } \\
\text { Ayọ̀ HTS } \\
\text { 'Ayo went (th }\end{array}$ & $\begin{array}{l}\text { lọ } \\
\text { go } \\
\text { ere).' }\end{array}$ & $\leftarrow$ & $\begin{array}{l}\text { Ayọ̀ } \\
\text { Ayọ̀ }\end{array}$ & $\begin{array}{l}\text { ó } \\
\text { HTS }\end{array}$ & $\begin{array}{l}\text { lọ } \\
\text { went }\end{array}$ \\
\hline (b) & $\begin{array}{ll}\text { Dàda á } \\
\text { Dada HTS } \\
\text { 'Dada carried }\end{array}$ & $\begin{array}{l}\text { gbe } \\
\text { carry it } \\
\text { it.' }\end{array}$ & $\leftarrow$ & $\begin{array}{l}\text { Dàda } \\
\text { Dada }\end{array}$ & $\begin{array}{l}\text { ó } \\
\text { HTS }\end{array}$ & $\begin{array}{l}\text { gbe } \\
\text { carry it }\end{array}$ \\
\hline (c) & $\begin{array}{l}\text { Oúnjẹ ẹ́ } \\
\text { food HTS } \\
\text { 'Food is avail }\end{array}$ & $\begin{array}{l}\text { wà } \\
\text { exist } \\
\text { able.' }\end{array}$ & $\leftarrow$ & $\begin{array}{l}\text { Oúnjẹ } \\
\text { food }\end{array}$ & $\begin{array}{l}\text { ó } \\
\text { HTS }\end{array}$ & $\begin{array}{l}\text { wà } \\
\text { exist }\end{array}$ \\
\hline
\end{tabular}

The precise function of the V-syllable (henceforth, the HTS) has long been a subject of debate among Yorùbá Linguists, who have variously called it (a) a "Subject-Predicate Junction Marker" (Bamgbose 1967: 35); (b) a "Clitic" Adewole (1998: 55-56); (c) a "Subject Concord Marker (Courtenay 1968: 71-74; Stahlke 1974: 177; Fresco 1970: 79-80); (d) a "Past/Present tense marker" (Awobuluyi 1975, 1978, 1992, 2008); (e) a "Concord Marker" (Bamgbose (1980: 197); and (f) an "Agreement Marker" (Dechaine 1993: 84, 483). In their own relatively recent contribution to that debate, Bisang and Sonaiya (1999) call the HTS "an operator which actualises or validates the relationship between a predicate and a subject within a state of affairs." Put more simply, this claim, as one understands it, affirms that the HTS serves to indicate that the action or process denoted by a predicate actually took place or occurred. The aim of the present contribution is to show that there is good reason to doubt that this is the real function of the element.

\section{The HTS as a Validator of Actualized Processes/States}

Bisang and Sonaiya (1999: 9f.) say the function of the HTS is to validate predicative relationships, i. e. to confirm that the actions or processes denoted by predicates actually 
occurred or came to pass. That being the case, there should be no sentences containing 'actualized' predicates that feature no HTS in the language. However, contrary to this expectation, such sentences regularly occur in the Èkó and the Ìjerò (Ekiti) regional varieties of the language as in

\section{2 i Èkó}

(a) $\mathrm{Mi}$ ri I saw it

'I saw it'

(b) Mi lọ, mi sì tètè padà

I went I and early returned

'I went and came back early/quickly'

ii İjerò (Èkìtì)

(a) $\mathrm{Mi}$ lọ

I went

'I went (there).'

(b) Mi gbe

I carried-it

'I carried/lifted it'

(c) Mi jẹun

I ate-thing

'I ate (a meal)'

Going by the unambiguous meanings of these examples, the various actions denoted by the predicates there are all understood to have taken place. Yet there is no trace of the HTS anywhere in them, and that can only logically mean that that element has nothing to do with validating actualized predicates. This conclusion would appear confirmed by further data relating to Bisang and Sonaiya's next claim about the HTS and negators.

\section{The Incompatibility of HTS with kò and other Negators}

Bisang and Sonaiya (1999: 11-15) note that the HTS does not co-occur with the negators kò 'not' and kì 'not' as well as with the conditional ìbáà 'even if'. They then take that as proof positive that the HTS truly validates only actualized predicates, and not predicates that were not actualized, i. e. that did not occur or come pass. Apparently unknown to them, however, the HTS does occur with the negators in the (Èkìì) regional variety of the language (cf. Olúmúyìwá 2006: 34f.), as in

(a) Ayọ́ $\quad$ ọ̀ $\quad$ lọ $\leftarrow$ Ayọ̀ ' è $\quad$ lọ $\leftarrow$ Ayọ̀ ó kè lọ Ayọ̀-HTS Neg go Ayọ̀ HTS Neg go Ayọ̀ HTS Neg go 'Ayọ̀ did not go (there)'

(b) Mé è gbe $\leftarrow \mathrm{Mi}^{\prime}$ è gbe $\leftarrow$ Mi ó kè gbe I-HTS Neg carry-it I HTS Neg carry it I HTS NEG carry it 'I didn't carry it.'

(c) Á à gbe $\leftarrow$ A ' è gbe $\leftarrow$ A ó kè gbe We-HTS NEG carry-it We HTS NEG carry it We HTS NEG carry-it 'We didn't carry it.'

The co-occurrence of the HTS with the negators kò 'not' and kì 'not' as well as with the conditional ìbáà 'even if' is not completely unknown in Standard Yorùbá either. According to 
Awobuluyi (1992: 28), the Standard Yorùbá second person singular unemphatic pronoun usually written and pronounced as $\mathbf{0}$ is actually a fusion of $\mathbf{0}$ (from ìwo 'you emph. sing') and the HTS, ó. (Lending empirical support to that analysis is ùg ${ }^{\mathrm{w}} \mathrm{o}$ 'you, singular, emphatic', which is similarly a fusion of $u^{\mathrm{w}}{ }^{\mathrm{o}}$ and ó t the HTS in AO dialect; on this, see Taiwo (2005: 78).) The fused form of that pronoun regularly co-occurs with negators as in

4 (a) $\mathrm{O}$ kò lọ / $\mathrm{O}$ ò lọ you-HTS Neg go / you Neg go 'You (sing) didn't go (there).'

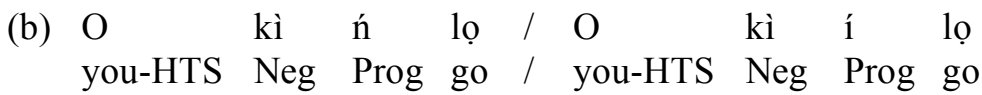

'You don't go (there).'

$\begin{array}{llllll}\text { (c) Ò } & \text { báà } & \text { lọ } & \text { O } & \text { ìbáà lo } & \text { lo } \\ \text { you-HTS } & \text { even-if } & \text { go } & & \text { you-HTS } & \text { even-if } \\ \text { go }\end{array}$ 'Even if you go (there)...'

Not only does it follow from these types of examples that, contra Bisang and Sonaiya, the HTS indeed can co-occur with the negators, it also follows that the HTS could not possibly be a validator of predicates since it co-occurs with processes and events that are clearly marked as not having occurred or come to pass.

\section{$4 \quad$ THE HTS in Focus Constructions}

Bisang and Sonaiya (1999: 15f.) feel that "the presence of the focus particle ni does not provide the right environment for the felicitous use of the HTS". And yet they paradoxically contend that the same "particle ni" "serves the purpose of a copula". Now, assuming just for the sake of argument that this particular claim of theirs is right, it follows that the expression below,

5 Ayọ̀ ni olè náà

Ayọ̀ cop thief the

'Ayọ is the thief.'

makes a "validated or actualized" predication of NP, Ayọ̀. For that reason, it should feature the HTS. But, contrary to that expectation and as Bisang and Sonaiya themselves admit, the HTS is actually not permitted there, and the only relevant conclusion one can draw from that is that the element has nothing to do with validating or actualizing predicates since, on the evidence of the above example, that can be achieved without it.

\section{Conclusion}

The various examples cited above from Standard Yorùbá and some of its regional varieties feature cases in which the HTS fails to occur where Bisang and Sonaiya's (1999) view requires it to occur, as well as cases where it occurs totally contrary to expectations based on that view. In other words then, those examples show that the view makes wrong predictions concerning the Yorùbá language. In effect, Awobuluyi (1978: 49) accurately foresaw this state of affairs when he said: "There has long been uncertainty among grammarians as to the precise [...] function of the syllable. It seems very doubtful whether a perfect solution will ever be found to this problem". However, not wishing to discourage any brave souls from ever trying their hands at the problem, one prefers to simply say here that the last word is definitely yet to be said on it. 


\section{References}

Adewole, Lawrence (1998): "Another visit to the Yorùbá High Tone Syllable". Afrikanistische Arbeitspapiere (AAP) 53: 91-106.

Awóbùlúyì, Ọládélé (1975): "On 'the Subject Concord Prefix' in Yorùbá". Studies in African Linguistics 6: 215-238.

Awóbùlúyì, Oládélé (1978): Essentials of Yorùbá Grammar. Oxford University Press Nigeria.

Awóbùlúyì, Ọládélé (1992): "Aspects of Contemporary Standard Yorùbá in Dialectological Perspective". In: Isola, Akinwumi (ed.): New Findings in Yorùbá Studies. Ibadan/Lagos: 1-79. (= J. F. Odunjo Memorial Lecture Series 3).

Awóbùlúyì, Ọládélé (2008): Èkớ İ ệdá-Ộọ̀ Yorùbá. Àkúrẹe.

Bámgbóșé, Ayọ̀ (1967): A Short Yorùbá Grammar. Ibàdàn.

Bámgbóṣé, Ayọ̀ (1980): "Pronouns, Concord and Pronominalization". Afrika and Übersee. Sprachen. Kulturen 63/2: 189-198.

Bámgbósé, Ayọ̀ (1990): Fonớlơjì àti Gírámà Yorùbá. Ibàdàn.

Bisang, Walter/Sonaiya, Remi (1999): "The functional Motivation of the high Tone Syllable in Yorùbá". JALL 20: 1-19.

Courtenay, Karen (1968): A Generative Phonology of Yorùbá. Ph.D. dissertation. Los Angeles.

Déchaine, Rosemary (1993): "Predicates Across Categories. Towards a category-neutral Syntax". Doctoral dissertation. Massachusetts.

Fresco, Edward (1970): "Topics in Yorùbá Dialect Phonology". Studies in African Linguistics, Supplement 1. Los Angeles.

Olúmúyíwà, Tèmítọ́pẹ (2006): Àwon Wúnrẹn Onitumọ̀ Gírámà Nínú Àwọn Àárín Gbùngbùn Yorùbá. Ph.D. Thesis. Àkùngbá-Àkókó (Nigeria).

Stahlke, Herbert (1974): "Pronouns and Islands in Yorùbá Studies". African Linguistics 5: 171-204.

Taiwo, Oyè (2005): Negation in the AO dialect of Yorùbá. Ph.D. Thesis. Ibadan. 